\title{
Assemblages of Fishes below the Lowermost Dam in Protected Reach in the Yangtze River Main Stream: Implications for River Management
}

\author{
Junyi Li, ${ }^{1,2}$ Hui Zhang, ${ }^{2}$ Danqing Lin, ${ }^{1,2}$ Jinming Wu, ${ }^{2}$ Chengyou Wang, \\ Xuan Xie, ${ }^{1,2}$ and Qiwei Wei ${ }^{2}$ \\ ${ }^{1}$ College of Life Science, Southwest University, Chongqing, China \\ ${ }^{2}$ Key Laboratory of Freshwater Biodiversity Conservation, Ministry of Agriculture of China, \\ Yangtze River Fisheries Research Institute, Chinese Academy of Fishery Sciences, Wuhan, China \\ Correspondence should be addressed to Qiwei Wei; weiqw@yfi.ac.cn
}

Received 7 July 2016; Accepted 20 September 2016

Academic Editor: Kaiyu He

Copyright (C) 2016 Junyi Li et al. This is an open access article distributed under the Creative Commons Attribution License, which permits unrestricted use, distribution, and reproduction in any medium, provided the original work is properly cited.

\begin{abstract}
Now more and more ecologists concern about the impacts of dam construction on fish. However, studies of fishes downstream Gezhouba Dam were rarely reported except Chinese sturgeon (Acipenser sinensis Gray). In this study, catch investigations and five hydroacoustic detections were completed from 2015 to 2016 to understand the distribution, size, and categories of fishes and their relationship with the environmental factors below Gezhouba Dam in protected reach in the Yangtze River main stream. Results showed significant differences in fish distribution and TS (target strength) between wet and flood seasons. Mean TS in five hydroacoustic detections were $-59.98 \mathrm{~dB},-54.70 \mathrm{~dB},-56.16 \mathrm{~dB},-57.90 \mathrm{~dB}$, and $-59.17 \mathrm{~dB}$, respectively, and dominant fish species are Coreius guichenoti (Bleeker), Siniperca chuatsi (Basilewsky), and Pelteobagrus vachelli (Richardson). In the longitudinal direction, fish preferred to stay in some specific sections like reaches $2,4,7,8,11$, and 16 . Since hydrology factors change greatly in different seasons, environmental characteristics vary along the reaches, and human activities play an important role in the fish behavior, it is concluded that great cross-season changes in hydrology lead to the differences in TS and fish assemblages and that geography characteristics, especially channel geography, together with human activities influence fish longitudinal distribution. This finding provides basic knowledge of spatiotemporal distribution and assemblages of fishes in the extended reaches downstream Gezhouba Dam. In addition, it offers implications for river management. It could also serve as reference of future research on fish habitat.
\end{abstract}

\section{Introduction}

Yangtze River is the largest river in China and the third largest in the world. It originates in mount Tunggula and flows into the East China Sea, with the total length of about 6300 kilometers. The complex geological environment and climate conditions bring Yangtze River a high biodiversity [1]. There are more than 360 species of freshwater fishes in the Yangtze River. This river exhibits a seasonal flow. And water temperature is high in the summer and low in the winter. Other ecological environments also vary from season to season. Gezhouba Dam ( lowermost dam in the Yangtze
River), part of the Three Georges water conservancy project, was the first dam in the Yangtze main stream and located in Yichang city, Hubei province, China, about 40 kilometers away downstream Three Georges Dam.

With the development of the acoustic methods, hydroacoustic technology has been used in fisheries research successfully for decades. It was often used to estimate fish abundance and distribution and observe fish behaviors like swimming speed or direction not only in the marine but also in the river. This technology provides a convenient and direct means to observe fish in situ without disturbance or damage of various aquatic systems [2], and it has been successfully 
used to monitor the fish in river both vertically $[3,4]$ and horizontally [5]. Horizontal sonar is usually used in shallow waters to study the fish size, migration, and abundance in the upper layer waters [6-8], and the "dead-zone" of layer waters was detected [9], while vertical sonar has been well applied to understanding of fish distribution and density in various waters including seawater and freshwater [2, 4]. Vertical sonar is also widely used in Chinese rivers [10-12]. Hydroacoustic technique has many advantages over traditional methods in studying fish size, abundance, and swimming speed, and it reduces manpower and reflects the fish behavior in natural state and is also less environment-dependent.

There existed more than 90 fish species in downstream section of the Gezhouba Dam in 1980s at the beginning of its construction. Among these species, there are some endangered and protected species at China national animal protection level, such as Chinese sturgeon (Acipenser sinensis Gray, CR, in the IUCN Red list) and Dabry's sturgeon. However, investigations on the catches in last decades showed that the reduction trend in fish species and fishery resources has become apparent in this downstream section $[13,14]$. Since the construction of Three Gorges Dam, spatiotemporal distribution of dominant species was influenced by the changes in hydrological conditions [15]. Therefore, protection of fishery resources is of great significance, and the knowledge of the fish distribution and behavior is essential for river management.

Many studies of fish size and density in the downstream area of the Gezhouba Dam were carried out. However, almost all of them focused only on the area near the dam and the limited species like Chinese sturgeon (Acipenser sinensis Gray) $[12,15,16]$, and the fish distribution in extended section remains unknown.

In this present study, acoustic detections coupled with fish sampling and the other datum collected were performed and this study is aimed at (1) understanding the fish distribution in the extended river section in downstream reach of Gezhouba Dam and its differences in different seasons, (2) finding out relations between the fish behaviors and environmental factors, (3) providing valuable information for fishery management and fish potential habitat.

\section{Materials and Methods}

2.1. Study Area. The study area covers the protected river reaches from downstream Gezhouba Dam (rkm $1678 \mathrm{~km}$ ) to Songzi River (rkm 1598), with the span of about $80 \mathrm{~km}$ (Yangtze River estuary was defined as river kilometer (rkm) 0 ). The geomorphology of this area changes apparently from mountainous to flat and its hydrological characteristics are regulated by Gezhouba Dam and Three Georges Dam. The average annual flow discharge and water level at Yichang Hydrological Monitoring Station (YHMS) from 1950 to 2000, respectively, were $13900 \mathrm{~m}^{3} / \mathrm{s}$ and $43.8 \mathrm{~m}$ [17]. In the study area, there are two tributaries, one is Qingjiang River which flows into the Yangtze River, and the other named Songzi River flows out. The reaches are microbend straight from Gezhouba Dam (rkm 1768) to Yidu city (rkm 1633) and tortuous in the last $35 \mathrm{~km}$ (Figure 1). The geographical advantages (river flows through the whole Yichang city and the study area is located at the junction of the upper and middle Yangtze River) and economic development in this area result in frequent human activities like shipping, wading engineering, and sewage disposal, which brings about tremendous pressure to the protection of aquatic environment in this area.

2.2. Hydroacoustic Detections. Five acoustic detections were performed in different seasons from 2015 to 2016, using a fiberglass-reinforced plastic boat with the length $6.3 \mathrm{~m}$ and engine power $85 \mathrm{hp}$, respectively. The echo sounder was equipped with a $199 \mathrm{kHz}$ BioSonics DT-X with a $6.7^{\circ}$ splitbeam transducer and set to a source level of $221.0 \mathrm{~dB}$ re $1 \mu \mathrm{Pa}$ at $1 \mathrm{~m}$ and a receiver sensitivity of $-51.3 \mathrm{~dB}$ re $1 \mu \mathrm{Pa}$. While detecting, the pulse duration was $0.4 \mathrm{~ms}$ and pulse rate was 5 pings/s.

The transducer was anchored on the right side of the boat and at a depth $0.5 \mathrm{~m}$ into the water vertically so as to sample the entire water column from $1.5 \mathrm{~m}$ below the water surface to $0.5 \mathrm{~m}$ above the bottom. The vertical motion detection was performed at a speed of about $8-10 \mathrm{~km} / \mathrm{h}$ with zigzag transects using a GPS receiver (JRC, Tokyo, Japan). It took 4 days to complete one detection due to the limited longitudinal detection distance of approximately $25 \mathrm{~km}$ one day. All the detections were performed in the daytime from 9:00 am to 17:00 pm (waterway transports make the detection in the night dangerous).

2.3. Fish Sampling. Fishing with various gillnets $(6,8 \mathrm{~cm})$ was carried out to obtain catches and fish species. Investigations on catches were conducted in July, November, December 2015, and January 2016. Two different habitat types were selected to investigate catches and these two habitats were classified into running water area with fast flows and pool water area with smooth water surface. In the running water area, drift nets were used to fish, while in the pool water area, set gill nets were used. Body length (in millimeter) and weight (in grams) of each fish were measured. The fish sampling area covered the $20 \mathrm{~km}$ downstream reach from Gezhouba Dam.

2.4. River Environment. In river environment description, the waterway kilometrage was divided according to channel chart supplied by the Yangtze River navigation agencies. Frequency of the human activities was divided into two categories, frequent or less. Frequent category was classified into two main types: wading engineering (type I) and anchorage zone (type II), and less frequent category refers to nonwading engineering and nonanchorage zone as previously mentioned (Table 1).

The data of water level and flow discharge were obtained from China Three Gorges Corporation. The detection date was divided into two periods, wet seasons (area I) and flood seasons (area II) (Figure 2).

2.5. Acoustic and Fish Density Analysis. Acoustic data were processed by Echoview software v. 4.9 (Myriax Pty Ltd, Hobart, TAS, Australia) with times-varied gain (TVG) of 

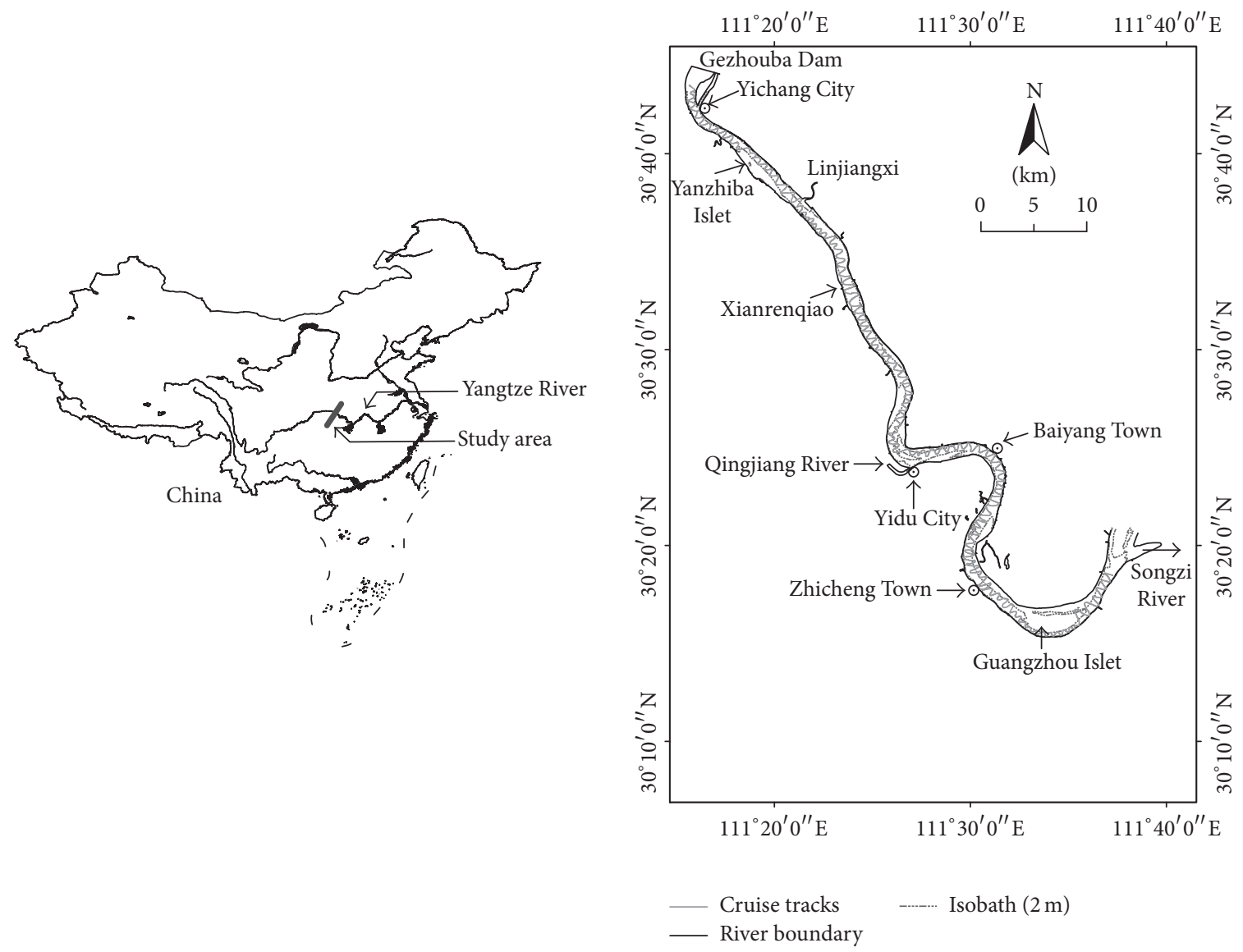

FIGURE 1: Study area, about $85 \mathrm{~km}$ in downstream reach of Gezhouba Dam, Yangtze River.

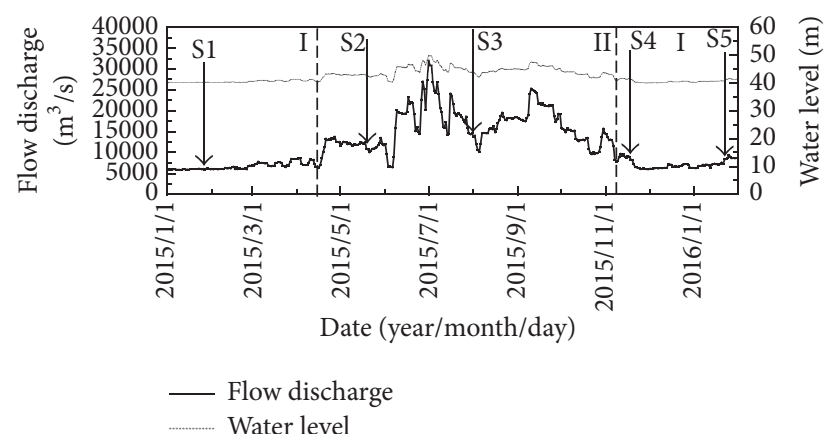

FIGURE 2: Flow discharge and water level in study area, $85 \mathrm{~km}$ downstream Gezhouba Dam, Yangtze River, 2015-2016.

$20 \log R$. However, not all the acoustic data were chosen. Data from water surface to $1 \mathrm{~m}$ below surface was filtered through a straight line due to the movement of vessels and the existence of "dead-zone." In the same way, data of $0.5 \mathrm{~m}$ above the river bottom were also removed. Only the data of $1 \mathrm{~m}$ under the water surface and $0.5 \mathrm{~m}$ above river bottom were retained to be analyzed. Some noise echoes were manually identified and deleted. In the single-echo detection (SED) echogram, the maximum one-way gain compensation was set to $10 \mathrm{~dB}$ with TS threshold being $-65 \mathrm{~dB}$ so as to exclude the echoes of fish below threshold value. When 4 single echoes were detected from one target with a maximum gap of 2 pings, one acceptable fish track detection (FTD) was obtained. Then information of every individual fish, such as TS, depth in water, location, and so on, was exported. The total length of every individual fish was usually calculated by a typical version equation: $\mathrm{TS}=19.1 \times \log (\mathrm{TL})-0.9 \times \log$ (Frequency) - 62.0 (Love, 1971) [18].

Fish density algorithm was calculated as follows:

$$
\begin{aligned}
& \bar{\sigma}_{b s}=10^{T S / 10}\left(\mathrm{~m}^{2}\right) \\
& \rho_{v S}=\frac{S_{v}}{\bar{\sigma}_{b s}}\left(\mathrm{~m}^{-3}\right) .
\end{aligned}
$$

$\bar{\sigma}_{b s}$ is the mean backscattering cross-section of all species $\left(\mathrm{m}^{2}\right), \rho_{v S}$ is the volumetric fish density in the region (fish/ $\left.\mathrm{m}^{3}\right)$, and $S_{v}$ is the linear mean $S_{V}$ value for the region $\left(\mathrm{m}^{2} /\right.$ $\left.\mathrm{m}^{3}\right)$.

\section{Results}

3.1. Assemblages of Fishes. Totally, 5687 fishes collected belong to 4 orders, 11 families, 38 genera, and 53 species. Of these 53 species, 13 species whose percentage $(\% \mathrm{~N})$, respectively, exceeded $1 \%$ of the total number of catches 
TABLE 1: Parameters of the divided reaches.

\begin{tabular}{|c|c|c|c|c|}
\hline Reach ID & Left rank & Right rank & $\begin{array}{l}\text { Human } \\
\text { activity }\end{array}$ & $\begin{array}{l}\text { Channel } \\
\text { geography }\end{array}$ \\
\hline 1 & Revetment & Revetment & Less & Curing \\
\hline 2 & Revetment & Mountain & Less & Curing \\
\hline 3 & Revetment & Revetment & Less & Straight \\
\hline 4 & Revetment & $\begin{array}{l}\text { Mountain } \\
\text { and riffle }\end{array}$ & $\begin{array}{l}\text { Frequent } \\
\text { (II) }\end{array}$ & Straight \\
\hline 5 & Revetment & Revetment & Less & Straight \\
\hline 6 & Revetment & Revetment & Less & Straight \\
\hline 7 & $\begin{array}{l}\text { Revetment } \\
\text { and riffle }\end{array}$ & $\begin{array}{l}\text { Revetment } \\
\text { and riffle }\end{array}$ & $\begin{array}{l}\text { Frequent } \\
\text { (II) }\end{array}$ & Straight \\
\hline 8 & Mountain & $\begin{array}{l}\text { Revetment } \\
\text { and riffle }\end{array}$ & Less & Curing \\
\hline 9 & $\begin{array}{l}\text { Revetment } \\
\text { and riffle }\end{array}$ & $\begin{array}{l}\text { Revetment } \\
\text { and riffle }\end{array}$ & $\begin{array}{l}\text { Frequent } \\
\text { (I) }\end{array}$ & Straight \\
\hline 10 & Revetment & $\begin{array}{l}\text { Revetment } \\
\text { and riffle }\end{array}$ & Less & Straight \\
\hline 11 & Mountain & $\begin{array}{l}\text { Revetment } \\
\text { and riffle }\end{array}$ & Less & Curing \\
\hline 12 & Revetment & $\begin{array}{l}\text { Revetment } \\
\text { and riffle }\end{array}$ & Less & Straight \\
\hline 13 & Revetment & Revetment & Less & Straight \\
\hline 14 & Revetment & Revetment & $\begin{array}{l}\text { Frequent } \\
\text { (I) }\end{array}$ & Straight \\
\hline 15 & $\begin{array}{l}\text { Revetment } \\
\text { and riffle }\end{array}$ & Revetment & Less & Curing \\
\hline 16 & $\begin{array}{l}\text { Revetment } \\
\text { and riffle }\end{array}$ & Mountain & Less & $\begin{array}{l}\text { Curing } \\
\text { and } \\
\text { straight }\end{array}$ \\
\hline
\end{tabular}

(5687) together account for $92.84 \%$ of the total number and $87.43 \%$ of the total weight of all catches. The breeding seasons of these 13 species are all in flood seasons about from March to August. 5 species are peculiar to the upper reaches of the Yangtze River whose stays are related to the lock and opening and flow discharge of Three Gorges Dam and Gezhouba Dam (Table 2).

3.2. Fish Vertical and TS Distribution. TS and TD (target depth) were obtained by Echoview analysis. Mean TS of the five detections were $-59.98 \mathrm{~dB},-54.70 \mathrm{~dB},-56.16 \mathrm{~dB}$, $-57.90 \mathrm{~dB}$, and $-59.17 \mathrm{~dB}$, respectively, and the mean target depth was $12.06 \mathrm{~m}, 11.47 \mathrm{~m}, 12.78 \mathrm{~m}, 13.72 \mathrm{~m}$, and $12.44 \mathrm{~m}$, respectively. Five acoustic detections indicated that differences of main TS distribution in various months were more significant than that of TD. The results of TS detection, respectively, in January 2015 November 2015, and January 2016 mainly ranged from $-63 \mathrm{~dB}$ to $-58 \mathrm{~dB}$, while TS detection in May and July 2015 mainly ranged from $-58 \mathrm{~dB}$ to $-52 \mathrm{~dB}$. In other words, target length converted from D1, D4, and D5 was bigger than that from D2 and D 3 after using Love's TS-TL equation. Signals of TS $>-30 \mathrm{~dB}$ were founded in each of five detections and they were maybe sent back by Chinese sturgeon (Acipenser sinensis Gray) [12]. The results of five TD detections concentrated in the depth layer from 5 to $15 \mathrm{~m}$ and
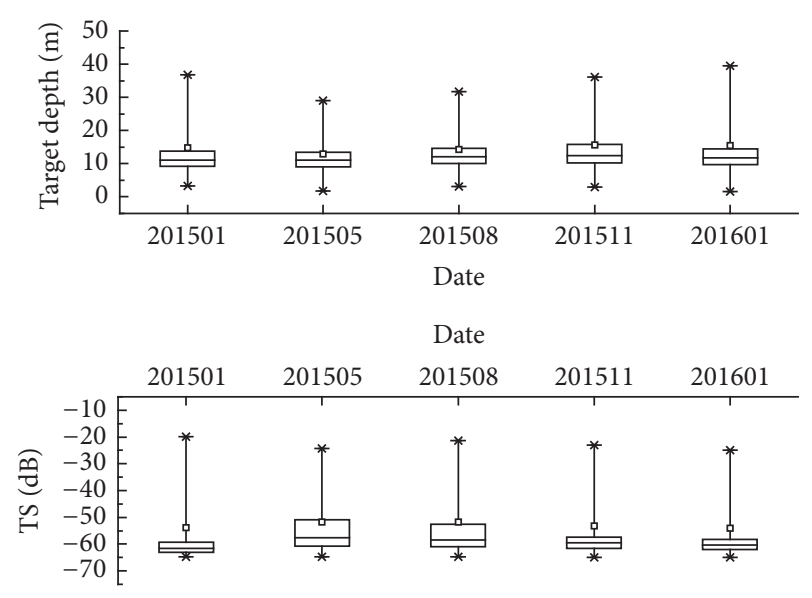

FIGURE 3: Fish vertical and TS distribution of the five hydroacoustic detections.

no obvious differences were found between these detections (Figure 3).

3.3. Fish Longitudinal Distribution. Fish longitudinal distribution was displayed by the fish density (ind/1000 $\mathrm{m}^{3}$ ). Eighty kilometers of distance from the Gezhouba Dam to Songzi River was divided into $5 \mathrm{~km}$ interval reaches according to the river geomorphology and there were 16 reaches in total. Shades of the color represented the area density. Black area represented high density and white represented low density.

The fish gathering places were different in the five acoustic detections. Fish longitudinal distribution differed greatly between the flood and wet season. B (the hydroacoustic detection in May 2015) found that fishes mainly were distributed in the first eight reaches, while $\mathrm{C}$ (the hydroacoustic detection in August 2015) found more even distribution of fishes. Few fishes were distributed in reach 9 and reach 14 with anchorage zone there, and fish preferred to stay in some specific reaches like reaches $2,4,7,811$, and 16 (Figure 4).

\section{Discussion}

Most of the studies by using hydroacoustic technology focused on fish biomass, size, and distribution in large estuaries, lakes, and rivers $[3,19,20]$. Few studies reported the research findings in the longer downstream river section of a dam. This study indicated that the combination of hydroacoustic technology and traditional fish sampling turned out to be an effective way to understand the fish spatiotemporal distribution and assemblages downstream Gezhouba Dam in different seasons. The results showed significant differences in fish longitudinal distribution and size in different seasons. Fish preferred to stay in the specific reaches where river channel was curving, where there were geographical riffles and less human activities. There may be three reasons for the results. First, great changes in hydrology in different seasons may result in the different fish longitudinal distribution, assemblages, and size. Second, the geography characteristics of river channel in this study area vary along the reaches, 
TABle 2: Catches catalogue downstream Gezhouba Dam, Yangtze River.

\begin{tabular}{|c|c|c|c|c|c|}
\hline Species & Number $(N)$ & $\% N$ & Weight $(W)$ & $\% W$ & Mean TL \\
\hline Coreius guichenoti (Bleeker) & 1665 & 29.28 & 363385.10 & 36.88 & 275 \\
\hline Siniperca chuatsi (Basilewsky) & 1492 & 26.24 & 199257.10 & 20.22 & 156 \\
\hline Pelteobagrus vachelli (Richardson) & 642 & 11.29 & 51837.86 & 5.26 & 154 \\
\hline Rhinogobio cylindricus Günther* & 330 & 5.80 & 25424.00 & 2.58 & 201 \\
\hline Parabramis pekinensis (Basilewsky) & 237 & 4.17 & 80081.90 & 8.13 & 283 \\
\hline Siniperca scherzeri Steindachner & 188 & 3.31 & 36476.70 & 3.70 & 214 \\
\hline Rhinogobio typus Bleeker & 145 & 2.55 & 20825.20 & 2.11 & 244 \\
\hline Xenocypris davidi Bleeker & 130 & 2.29 & 11253.90 & 1.14 & 196 \\
\hline Mystus macropterus (Bleeker) & 113 & 1.99 & 19892.90 & 2.02 & 278 \\
\hline Xenocypris davidi Bleeker & 108 & 1.90 & 12287.60 & 1.25 & 146 \\
\hline Leiocassis crassilabris Günther & 95 & 1.67 & 6657.00 & 0.68 & 138 \\
\hline Carassius auratus (Linnaeus) & 77 & 1.35 & 21265.30 & 2.16 & 167 \\
\hline Leptobotia elongata (Bleeker)* & 58 & 1.02 & 12850.30 & 1.30 & 258 \\
\hline Cyprinus carpio Linnaeus & 52 & 0.91 & 40802.30 & 4.14 & 169 \\
\hline Pseudolaubuca sinensis Bleeker & 49 & 0.86 & 2858.80 & 0.29 & 173 \\
\hline Saurogobio dabryi Bleeker & 42 & 0.74 & 2664.00 & 0.27 & 183 \\
\hline Pelteobagrus fulvidraco (Richardson) & 35 & 0.62 & 2601.00 & 0.26 & 162 \\
\hline Silurus asotus Linnaeus & 27 & 0.47 & 15022.70 & 1.52 & 281 \\
\hline Squalidus argentatus (Sauvage et Dabry) & 24 & 0.42 & 678.60 & 0.07 & 122 \\
\hline Hemibarbus maculatus Bleeker & 18 & 0.32 & 2689.80 & 0.27 & 187 \\
\hline Pseudobrama simoni (Bleeker) & 16 & 0.28 & 658.90 & 0.07 & 145 \\
\hline Pelteobagrus nitidus (Sauvage et Dabry) & 14 & 0.25 & 309.50 & 0.03 & 128 \\
\hline Leiocassis longirostris Günther & 13 & 0.23 & 4842.30 & 0.49 & 307 \\
\hline Hypophthalmichthys molitrix (Cuvier et Valenciennes) & 11 & 0.19 & 2320.80 & 0.24 & 212 \\
\hline Coreius guichenoti (Sauvage et Dabry)* & 10 & 0.18 & 5494.60 & 0.56 & 360 \\
\hline Squaliobarbus curriculus (Richardson) & 9 & 0.16 & 2442.50 & 0.25 & 280 \\
\hline Silurus meridionalis Chen & 9 & 0.16 & 12231.90 & 1.24 & 545 \\
\hline Megalobrama amblycephala Yih & 8 & 0.14 & 5533.70 & 0.56 & 371 \\
\hline Pseudobagrus pratti Günther & 7 & 0.12 & 327.20 & 0.03 & 184 \\
\hline Hemiculter bleekeri Warpachowsky & 6 & 0.11 & 103.40 & 0.01 & 128 \\
\hline Pseudobagrus truncates (Regan) & 6 & 0.11 & 102.00 & 0.01 & 117 \\
\hline Hemiculter leucisclus (Basilewsky) & 5 & 0.09 & 204.90 & 0.02 & 123 \\
\hline Ctenopharyngodon idellus (Cuvier et Valenciennes) & 5 & 0.09 & 13477.81 & 1.37 & 606 \\
\hline Tinca tinca (Linnaeus) & 5 & 0.09 & 1690.90 & 0.17 & 284 \\
\hline Culter alburnus Basilewsky & 5 & 0.09 & 2185.60 & 0.22 & 167 \\
\hline Odontobutis obscura (Temminck \& Schlegel) & 3 & 0.05 & 34.40 & $<0.01$ & 10 \\
\hline Hyporhamphus intermedius (Cantor) & 3 & 0.05 & 317.90 & 0.03 & 201 \\
\hline Jinshaia sinensis (Sauvage et Dabry) ${ }^{*}$ & 3 & 0.05 & 147.50 & 0.01 & 101 \\
\hline Parabotia fasciata Dabry & 2 & 0.04 & 82.40 & 0.01 & 188 \\
\hline Lepturichthys fimbriata (Günther) & 2 & 0.04 & 11.80 & $<0.01$ & 116 \\
\hline Culter molitorella (Cuvier et Valenciennes) & 2 & 0.04 & 170.70 & 0.02 & 219 \\
\hline Culter mongolicus mongolicus (Basilewsky) & 2 & 0.04 & 1090.50 & 0.11 & 375 \\
\hline Culter oxycephaloides Kreyenberg et Pappenheim & 2 & 0.04 & 1016.10 & 0.10 & 431 \\
\hline Myxocy prinus asiaticus (Bleeker) & 2 & 0.04 & 235.40 & 0.02 & 183 \\
\hline Pelteobagrus eupogon (Boulenger) & 2 & 0.04 & 110.00 & 0.01 & 19 \\
\hline Saurogobio gymnocheilus Lo Yao \& Chen & 1 & 0.02 & 67.60 & 0.01 & 224 \\
\hline Opsariichthys bidens Günther & 1 & 0.02 & 32.00 & $<0.01$ & 15 \\
\hline Misgurnus anguillicaudatus (Cantor) & 1 & 0.02 & 37.00 & $<0.01$ & 162 \\
\hline Channa argus (Cantor) & 1 & 0.02 & 781.50 & 0.08 & 432 \\
\hline Gobiobotia filifer (Garman) & 1 & 0.02 & 7.50 & $<0.01$ & 107 \\
\hline Aristichthys nobilis (Richardson) & 1 & 0.02 & 59.40 & 0.01 & 180 \\
\hline Rhinogobio ventralis Sauvage et Dabry* & 1 & 0.02 & 179.60 & 0.02 & 251 \\
\hline Spinibarbus sinensis (Bleeker) & 1 & 0.02 & 224.10 & 0.02 & 267 \\
\hline Total & 5687 & 100 & 985343.47 & 100 & \\
\hline
\end{tabular}

Number $(N)$, percentage number $(\% N)$, weight (in grams, $W)$, percent weight $(\% W)$, and mean total length (mm, mean TL). * means that this species is peculiar to the upper reaches of the Yangtze River. 


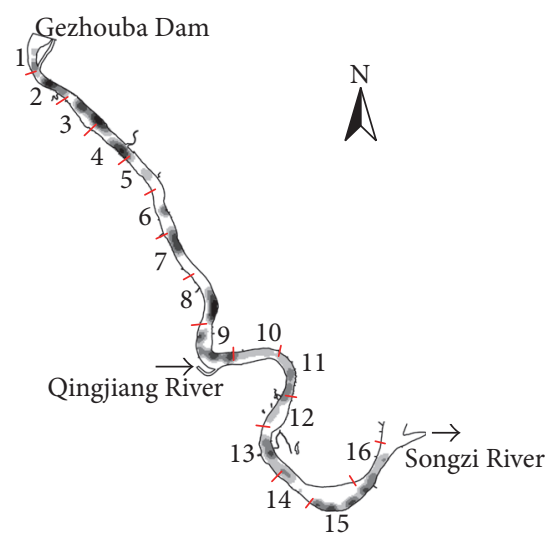

01/2015 (month/year)

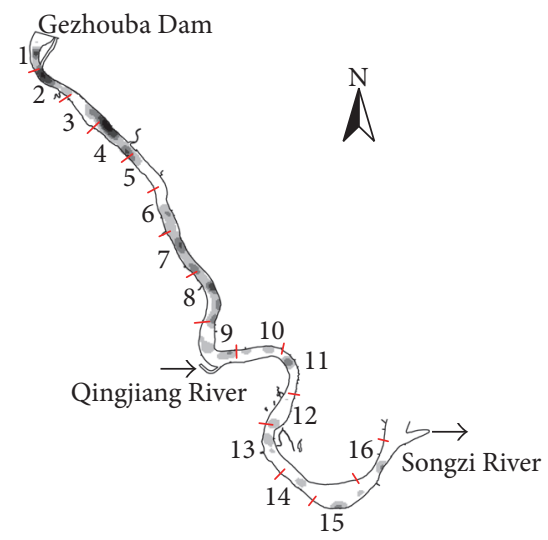

05/2015 (month/year)

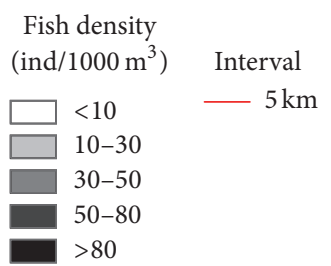

(b)

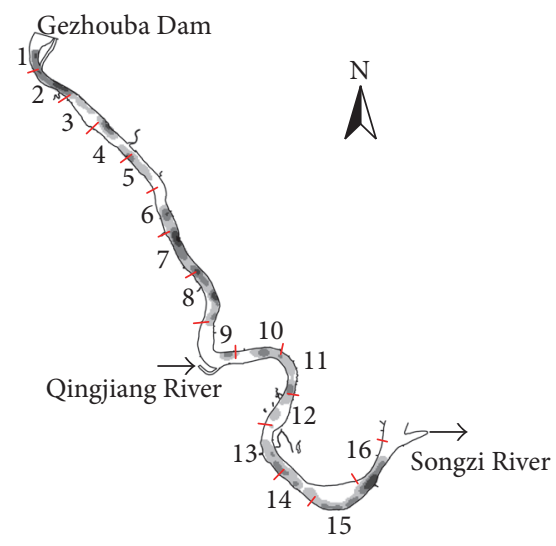

08/2015 (month/year)

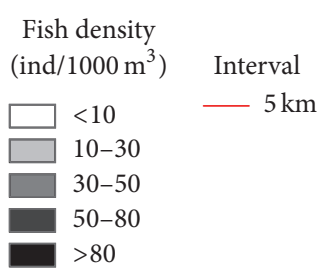

(c) (a)

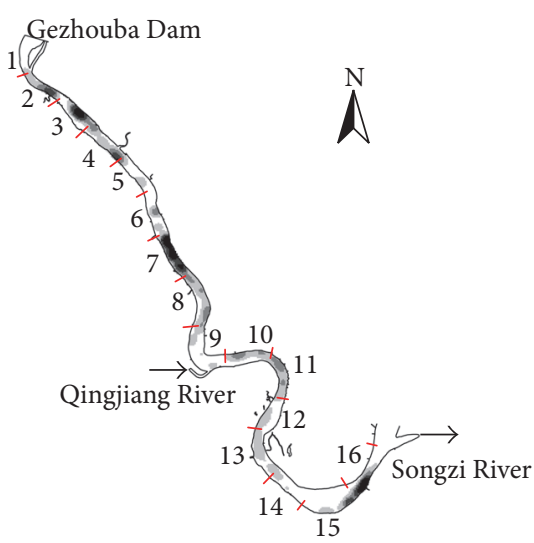

$11 / 2015$ (month/year)

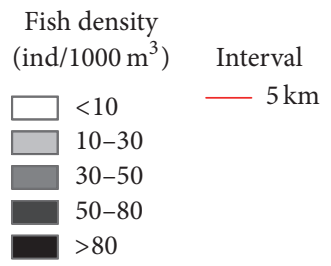

(d)

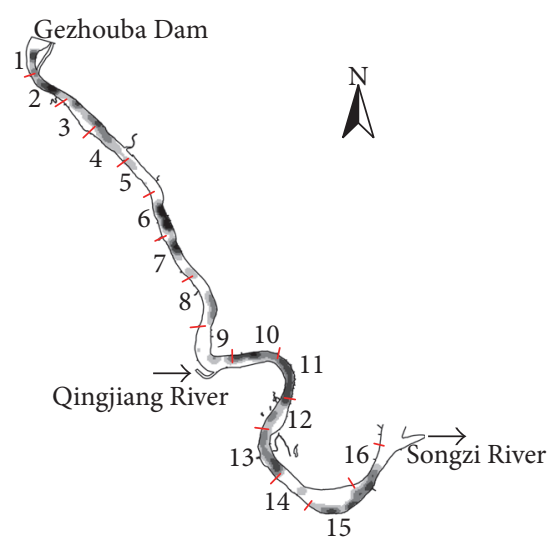

01/2016 (month/year)

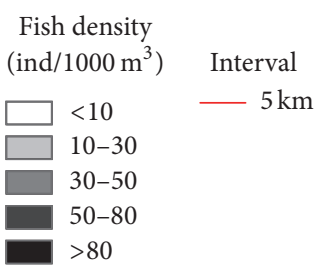

(e)

FIGURE 4: Fish longitudinal distribution of the five hydroacoustic detections. (a) Hydroacoustic detection in January 2015; (b) hydroacoustic detection in May 2015; (c) hydroacoustic detection in August 2015; (d) hydroacoustic detection in September 2015; (e) hydroacoustic detection in January 2016.

which may influence fish gathering. Third, human activity is also a limiting factor.

Fish distribution and abundance in rivers displayed longitudinal zonation from upstream to downstream [20, 21]. Water level changes from May to October in the Yangtze River, and many fishes migrate when water level changes seasonally in the Yangtze River. In flood seasons, hydrologic factors like water temperature, depth, flow velocity, flow discharge, and nutrients change rapidly. High flow discharge could bring high flow velocity and more nutrients, which play an important role in fish behaviors including migration, feeding, and reproduction. In addition, flood seasons are fish breeding periods for most of the species in this study area. Riverine fish assemblages change rapidly or gradually with 
rapid or gradual changes in the physicochemical habitat [22]. Therefore, great differences in mean TS and fish longitudinal distribution between flood and wet seasons were found in this study.

Fish habitat is an essential component of ecosystem [23], while studies of fish habitats downstream Gezhouba Dam were merely limited to the habitats of large endangered individual Chinese sturgeon (Acipenser sinensis Gray) [2427]. This study covers different reaches with different geography characteristics that are habitats of various fish species. Reaches 4 and 7 of this study area are straight geomorphologically with riffles where fish preferred to inhabit. Ranges of velocity and depth around the island are wider than those in other straight river sections without islands [28]. Reaches with riffles represent more complex environment beneficial for fish to avoid interference and predators. There also exists anchorage zone in reaches 4 and 7 , and human waste such as deserted food and sanitary waste are discharged directly into the river here, which provides much more food and nutrients for these two reaches and make them an ideal habitat place for fish to feed and avoid disadvantage behaviors. Reaches 2, 8, 11, and 16 are curing section with mountains and riffles and with less human activities. Therefore, the environment of these reaches is much more natural and less disturbed externally. This may explain why fish preferred to stay in these reaches.

There are still some limitations in this study. Because of the fishing ban seasons (from March to May every year before 2015 and February to May from 2016), fish sampling and hydroacoustic detections could not be conducted simultaneously. The calculation results of the corresponding fish length of five acoustic detections were $1.64 \mathrm{~cm}, 3.09 \mathrm{~cm}, 2.59 \mathrm{~cm}$, $2.10 \mathrm{~cm}$, and $1.80 \mathrm{~cm}$, respectively, by using the typical version equation: $\mathrm{TS}=19.1 \times \log (\mathrm{TL})-0.9 \times \log$ (Frequency $)-62.0$ [18]. However, these calculation results significantly differ from actual measurement results of fish length of the catches. Since few researches on conversion equations of TS values and fish length about fish species in Yangtze River were reported, there have been no appropriate equations to match these two results so far. According to the average annual flow discharge and water level at YHMS in the last 50 years (from 1950 to 2000) and the situation of hydroacoustic detection in recent years $[12,17]$, the periods of wet seasons and flood seasons are almost the same every year. They could be divided into flood seasons and wet seasons (Figure 2). Therefore, five hydroacoustic detections were conducted in these two seasons: three in the wet seasons and two in the flood seasons. What is more, high flow discharge (when flow discharge $>20000 \mathrm{~m}^{3} / \mathrm{s}$ ) in the flood seasons brings high velocity and much more bubbles which make the hydroacoustic detection unsafe and inaccurate. Therefore five hydroacoustic detections were conducted in the two periods (Figure 2, wet seasons and flood seasons).

Previous studies focused on the distribution and spawning grounds of Chinese sturgeon $[16,24,29]$ or fish assemblages and behaviors in the downstream zone adjacent to Gezhouba Dam. This research extended the study area to $80 \mathrm{~km}$ away from Gezhouba Dam to offer the knowledge of fish longitudinal distribution and size in different seasons. Our study results demonstrated that fish distribution was influenced by both environment factors and human activities. Fish habitat loss has become a big threat to aquatic biodiversity [1]. Although quantitative factors like velocity, dissolved oxygen, and fish assemblages are not measured, the reaches of Yangtze River reported by this study where fish preferred to inhabit could be considered as potential fish habitats, which would be helpful for future research on fish habitat. Furthermore, how Gezhouba Dam affects the fish is still unknown, but the effects of Gezhouba Dam on fish survival were exemplified by the Acipenseriformes [30, 31]. Researches on the effects of Gezhouba Dam and conservations for fish biodiversity are also essential in the future work.

Based on this study findings, the suggestions for river management are as follows.

(1) Fishing ban seasons may be adjusted to containing the whole flooding seasons especially July and August since the breeding seasons of dominant fish species such as Coreius guichenoti (Bleeker), Siniperca chuatsi (Basilewsky), and Pelteobagrus vachelli (Richardson) in this study area are in the flooding seasons.

(2) Strengthen the supervision over poaching and overfishing in the specific reaches mentioned in this study where fishes prefer to inhabit.

(3) Select wading engineering location scientifically to avoid the loss of fish habitat.

\section{Competing Interests}

The authors declare that they have no competing interests.

\section{Acknowledgments}

Thanks are due to the members of the Endangered Fish Conservation Group of the Yangtze River Fisheries Research Institute, Chinese Academy of Fishery Sciences. This study was funded by the research (The Postenvironmental Impact Assessment of the Gezhouba Dam on the Yangtze River), which was supported by the China Three Gorges Corporation (no. 0799564), and it was also supported by the National Natural Science Foundation of China (no. 31602160).

\section{References}

[1] C. Fu, J. Wu, J. Chen, Q. Wu, and G. Lei, "Freshwater fish biodiversity in the Yangtze River basin of China: patterns, threats and conservation," Biodiversity \& Conservation, vol. 12, no. 8, pp. 1649-1685, 2003.

[2] J. Simmonds and D. Maclennan, Fisheries Acoustics: Theory and Practice, John Wiley \& Sons, New York, NY, USA, 2nd edition, 2007.

[3] J. Guillard, M. Simier, J.-J. Albaret, J. Raffray, I. Sow, and L. Tito de Morais, "Fish biomass estimates along estuaries: a comparison of vertical acoustic sampling at fixed stations and purse seine catches," Estuarine, Coastal \& Shelf Science, vol. 107, pp. 105-111, 2012.

[4] V. Samedy, M. Wach, J. Lobry et al., "Hydroacoustics as a relevant tool to monitor fish dynamics in large estuaries," Fisheries Research, vol. 172, pp. 225-233, 2015. 
[5] A. Duncan and J. Kubecka, "Patchiness of longitudinal fish distributions in a river as revealed by a continuous hydroacoustic survey," ICES Journal of Marine Science, vol. 53, no. 2, pp. 161$165,1996$.

[6] J. J. Burczynski and R. L. Johnson, "Application of dual-beam acoustic survey techniques to limnetic populations of juvenile sockeye salmon (Oncorhynchus nerka)," Canadian Journal of Fisheries \& Aquatic Sciences, vol. 43, no. 9, pp. 1776-1788, 1986.

[7] B. H. Ransom, S. V. Johnston, and T. W. Steig, "Review on monitoring adult salmonid (Oncorhynchus and Salmo spp.) escapement using fixed-location split-beam hydroacoustics," Fisheries Research, vol. 35, no. 1-2, pp. 33-42, 1998.

[8] J. Kubecka and M. Wittingerova, "Horizontal beaming as a crucial component of acoustic fish stock assessment in freshwater reservoirs," Fisheries Research, vol. 35, no. 1-2, pp. 99-106, 1998.

[9] F. R. Knudsen and H. Sægrov, "Benefits from horizontal beaming during acoustic survey: application to three Norwegian lakes," Fisheries Research, vol. 56, no. 2, pp. 205-211, 2002.

[10] X. Tan, M. Kang, J. Tao, X. Li, and D. Huang, "Hydroacoustic survey of fish density, spatial distribution, and behavior upstream and downstream of the Changzhou Dam on the Pearl River, China," Fisheries Science, vol. 77, no. 6, pp. 891-901, 2011.

[11] J. Tao, Y. Gao, Y. Qiao et al., "Hydroacoustic observation of fish spatial patterns and behavior in the ship lock and adjacent areas of Gezhouba Dam, Yangtze River," Acta Ecologica Sinica, vol. 30, no. 4, pp. 233-239, 2010.

[12] H. Zhang, C. Y. Wang, D. G. Yang, H. Du, Q. W. Wei, and M. Kang, "Spatial distribution and habitat choice of adult Chinese sturgeon (Acipenser sinensis Gray, 1835) downstream of Gezhouba Dam, Yangtze River, China," Journal of Applied Ichthyology, vol. 30, no. 6, pp. 1483-1491, 2014.

[13] G. L. Yu, Y. G. Xu, X. C. Tan, Z. L. Deng, and J. B. Chang, "Status of fisheries in the section below the Gezhouba Dam of the Yangtze River," Acta Hydrobiologica Sinica, vol. 23, pp. 662669, 1999 (Chinese).

[14] Q. Ma, P. C. Lin, H. Z. Liu, W. X. Cao, and X. Gao, "Effects of the gillnets on fish resources in the Yichang reaches of the Yangtze River," Sichuan Journal of Zoology, vol. 33, pp. 762-767, 2014 (Chinese).

[15] J. P. Tao, Y. T. Gong, X. C. Tan, Z. Yang, and J. B. Chang, "Spatiotemporal patterns of the fish assemblages downstream of the Gezhouba Dam on the Yangtze River," Science China Life Sciences, vol. 55, no. 7, pp. 626-636, 2012.

[16] Y. Qiao, X. Tang, S. Brosse, and J. Chang, "Chinese Sturgeon (Acipenser sinensis) in the Yangtze River: a hydroacoustic assessment of fish location and abundance on the last spawning ground," Journal of Applied Ichthyology, vol. 22, no. 1, pp. 140144, 2006.

[17] W. C. Yu and J. Y. Lu, Evolution of the Yangtze River and its Regulation, China Water Power Press, Beijing, China, 2005 (Chinese).

[18] R. H. Love, "Dorsal-aspect target strength of an individual fish," Journal of the Acoustical Society of America, vol. 49, no. 3, pp. 816-823, 1971.

[19] U. Krumme and A. Hanning, "A floating device for stationary hydroacoustic sampling in shallow waters," Fisheries Research, vol. 73, no. 3, pp. 377-381, 2005.

[20] R. M. Hughes and J. R. Gammon, "Longitudinal changes in fish assemblages and water quality in the Willamette River, Oregon," Transactions of the American Fisheries Society, vol. 116, no. 2, pp. 196-209, 1987.
[21] E. Habit, M. C. Belk, R. Cary Tuckfield, and O. Parra, "Response of the fish community to human-induced changes in the Biobío River in Chile," Freshwater Biology, vol. 51, no. 1, pp. 1-11, 2006.

[22] W. J. Matthews, "Fish faunal 'breaks' and stream order in the eastern and central United States," Environmental Biology of Fishes, vol. 17, no. 2, pp. 81-92, 1986.

[23] J. A. Stefferud, K. B. Gido, and D. L. Propst, "Spatially variable response of native fish assemblages to discharge, predators and habitat characteristics in an arid-land river," Freshwater Biology, vol. 56, no. 7, pp. 1403-1416, 2011.

[24] B. Kynard, Q. W. Wei, and F. E. Ke, "Use of ultrasonic telemetry to locate the spawning area of Chinese sturgeons," Chinese Science Bulletin, vol. 40, pp. 669-671, 1995.

[25] H. Du, Q. W. Wei, H. Zhang, Z. Liu, C. Wang, and Y. Li, "Bottom substrate attributes relative to bedform morphology of spawning site of Chinese sturgeon Acipenser sinensis below the Gezhouba dam," Journal of Applied Ichthyology, vol. 27, no. 2, pp. 257-262, 2011.

[26] X. Ban, Y. Du, H. Z. Liu, and F. Ling, "Applying instream flow incremental method for the spawning habitat protection of Chinese sturgeon (Acipenser sinensis)," River Research \& Applications, vol. 27, no. 1, pp. 87-98, 2011.

[27] C. Wang, B. Kynard, Q. Wei, H. Du, and H. Zhang, "Spatial distribution and habitat suitability indices for non-spawning and spawning adult Chinese sturgeons below Gezhouba Dam, Yangtze River: effects of river alterations," Journal of Applied Ichthyology, vol. 29, no. 1, pp. 31-40, 2013.

[28] X. Ban, H. Du, and Q. W. Wei, "Fish preference for hydraulic habitat in typical middle reaches of Yangtze River, China," Journal of Applied Ichthyology, vol. 29, no. 6, pp. 1408-1415, 2013.

[29] H. Zhang, Q. W. Wei, B. E. Kyanrd, H. Du, D. G. Yang, and X. H. Chen, "Spatial structure and bottom characteristics of the only remaining spawning area of Chinese sturgeon in the Yangtze River," Journal of Applied Ichthyology, vol. 27, no. 2, pp. 251-256, 2011.

[30] Q. W. Wei, F. F. Ke, J. M. Zhang et al., "Biology, fisheries, and conservation of sturgeons and paddlefish in China," Environmental Biology of Fishes, vol. 48, no. 1-4, pp. 241-255, 1997.

[31] J. M. Wu, C. Y. Wang, H. Zhang et al., "Drastic decline in spawning activity of Chinese sturgeon Acipenser sinensis Gray 1835 in the remaining spawning ground of the Yangtze River since the construction of hydrodams," Journal of Applied Ichthyology, vol. 31, no. 5, pp. 839-842, 2015. 

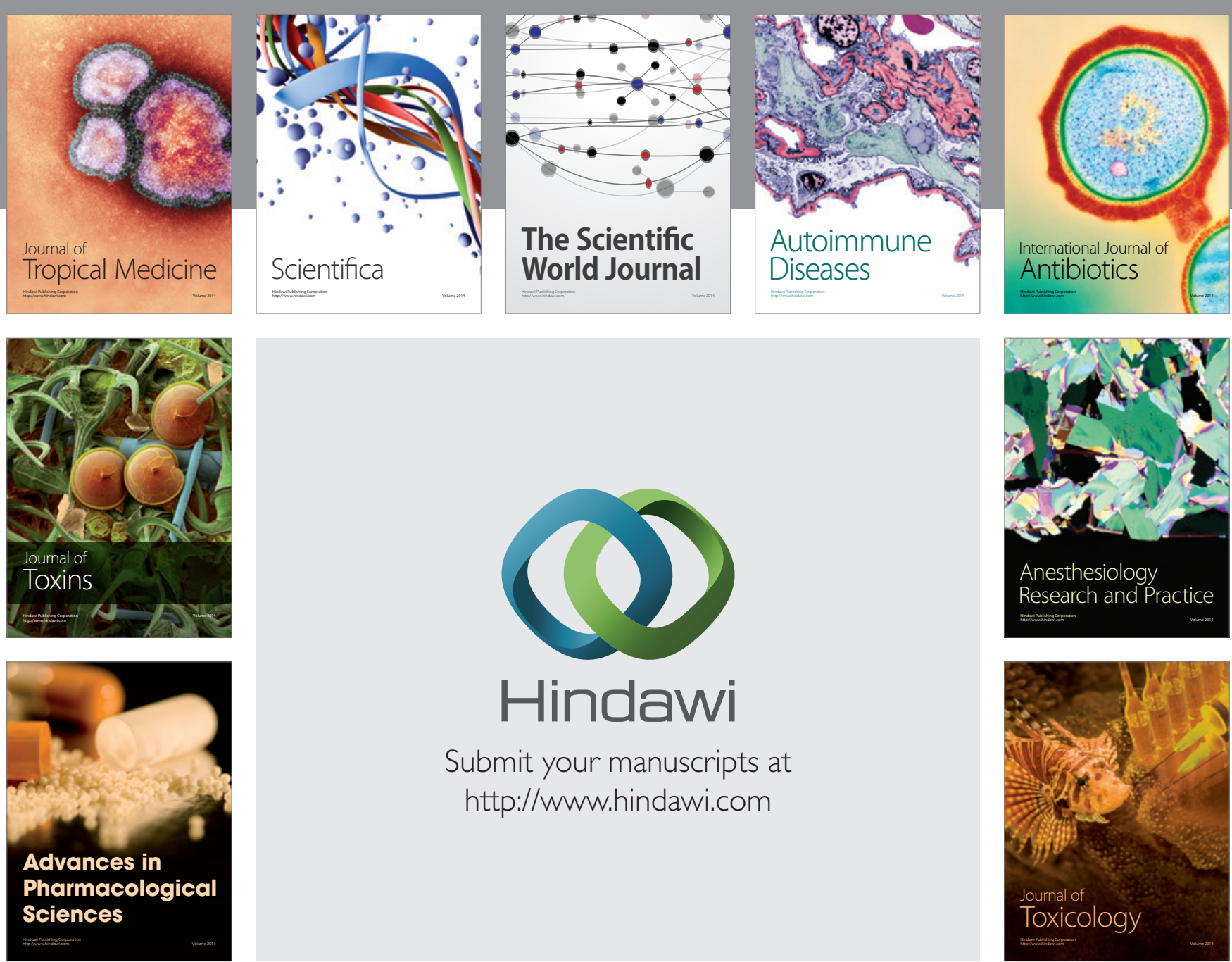

\section{Hindawi}

Submit your manuscripts at

http://www.hindawi.com
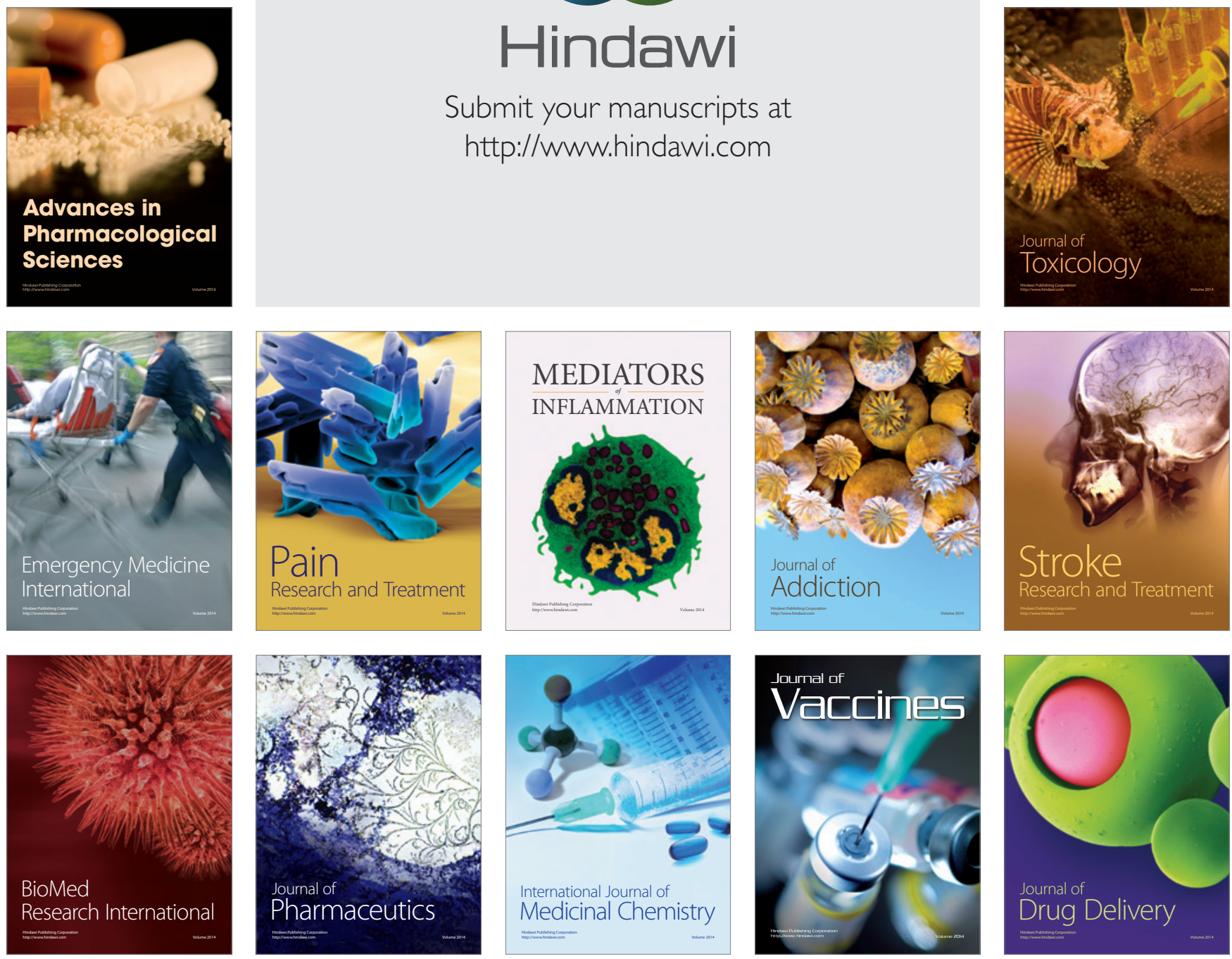